\title{
Etymologial Myths and Compound Etymologies in Rhyming Slang
}

\author{
Antonio Lillo \\ Department of English, University of Alicante, Spain
}

\begin{abstract}
Knowledge of how rhyming slang works has often led scholars and laypeople to assume, without a shred of evidence, that many words of unknown derivation have their origins in this form of slang. Some of these assumptions are based on the premise that, if two synonymous words or phrases rhyme, one of them must derive from the other, while others hinge on the supposed existence of a full form whose second element helps unravel the puzzle. This tendency to folk-etymologise by resorting to rhyme is also reflected in many terms resulting from a conflation of a non-rhyming slang word and an underlying rhyme, the former usually being regarded as an elliptical version of the full rhyming slang term, rather than one of its etymons. Drawing on data from a range of primary and secondary sources, this article examines the inner workings of a number of false but widely entertained rhyming slang etymologies and shows how some of the mechanisms that triggered them have long been used in the creation of genuine folk-etymological elaborations.
\end{abstract}

Keywords: rhyming slang; false etymology; folk etymology; word-formation

\section{Introduction}

Rhyming slang (henceforth RS) is a category of word-formation in which an expression, typically a double-stressed phrase, takes on the meaning of a word with which it rhymes. For example, rabbit and pork is used to mean 'a conversation' via the rhyme on talk and Quentin Tarantino comes to mean 'wine' by virtue of the rhyme on the slang vino. Frequently, however, only the first part of the phrase is used, as in "I wanted to

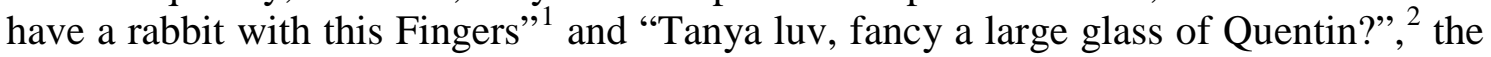
original link with the target word becoming a mere technicality.

Although no one knows how RS came into being, what little evidence there is does suggest it originated in the East End of London in the early nineteenth century. Bearing in mind that the earliest instance of this form of slang is found in H. Brandon's "Dictionary of the Flash or Cant Language", published in 1839, and that in the first edition of his Dictionary of Modern Slang, Cant, and Vulgar Words, John Camden Hotten points out that "the rhyming slang" (note the definite article) started "about twelve or fifteen years ago", ${ }^{3}$ we may at least conclude that there was a recognisable

\footnotetext{
${ }^{1}$ Norman, 39.

${ }^{2}$ Randall, 120.

${ }^{3}$ Hotten, Dictionary of Modern Slang.
} 
body of rhymes doing the rounds in London in the 1840s. In all likelihood, it was the capital's centrality as a hub of subcultures and a source of linguistic innovations that made RS persist with remarkable vitality, travel around the English-speaking world and develop its own specific forms in a host of geographical and social dialects, as demonstrated most recently by the work of Antonio Lillo and Terry Victor.

Because of its inherently cryptic nature, it may be reasonably assumed that at least one of the original purposes of RS was to serve as a secret code, and a playful one at that, thus aiding private communication and reinforcing group membership among beggars, criminals and costermongers. ${ }^{4}$ In fact, the playful secrecy of RS is still one of the reasons for its continued prevalence in the dialects of marginal groups, including criminals and drug addicts. ${ }^{5}$

Interestingly enough, it is also precisely because of its cryptic nature that RS has often been used as a master key to unlocking etymological conundrums. The belief is widespread among scholars and laypeople alike that many words can be explained as originating in this type of slang. Some of the explanations they give are based on coincidental rhyming links between synonyms, while others rest upon the mistaken assumption that many etymologically puzzling words are in fact abbreviations, their presumed full forms providing the key to their meaning. Sometimes, in a twist of irony, a word may well be conjectured to be clipped RS even though its "original" full form and hence its hidden rhyme are unknown. Jonathon Green, for example, notes that the obsolete phrase sling one's daniel 'to leave' is of unknown derivation, but might be 'lost rhy[ming] sl[ang] referring to some form of pack'. ${ }^{6}$ Similarly, Tony Thorne suggests that the mysterious steamboats 'drunk' "may have something to do with the use of a name such as 'Steamboat Bill', possibly in a lost rhyming-slang expression”. Whether these guesses stand up to scrutiny or not does not seem to matter much to the non-linguist, who tends to find RS etymologies (real and fanciful) irresistibly charming.

Contrary to what one might expect, the myths and conjectures that have been tossed around about the origin of certain RS terms are also of interest to the linguist, for the mechanisms underlying them may provide significant insight into the processes involved in the genesis of new words. Nancy A. Niedzielski and Dennis R. Preston argue in a different context that what non-linguists believe about language does have a bearing on linguistic change. "Folk linguistic beliefs," they claim, "may help determine the shape of language itself". ${ }^{8}$ It is hard to disagree with them. As far as lexis is concerned, what people believe about words and their origins matters too.

Drawing on data from a number of primary and secondary sources, my purpose in this article is to offer a glimpse into two intertwined areas of lexical research which remain largely unexamined: the false etymologies (or "etymythologies", to borrow Laurence Horn's felicitous coinage) of RS words and the role that folk-etymology plays in the creation of RS. Besides shedding light on some little-known aspects of slang etymology, this study seeks to provide a better understanding of the nature of RS as a word-making device in contemporary English.

\footnotetext{
${ }^{4}$ See Partridge, Words, Words, Words!, 30-31. Costermongers were street sellers of fruit, vegetables, fish and meat. Hotten noted that the London costermongers, numbering over 30,000 at the time of his writing, formed 'a distinct class, occupying whole neighbourhoods' and were 'cut off from the rest of metropolitan society by their low habits'.

${ }^{5}$ Smith; Lillo, "Rhyming Slang of the Junkie"; Bronson, 204-205.

${ }^{6}$ Green, Green's Dictionary of Slang. See also Quinion, 231; Robert Allen, 386.

${ }^{7}$ Niedzielski and Preston, viii.

${ }^{8}$ Ibid.
} 


\section{RS myths and how they get started}

It is striking to see, in dictionary after dictionary, how many non-RS words are widely thought to be RS. As with other etymological myths, these bits of misinformation have a funny habit of dying hard. Some of the usual suspects are chew the fat 'to talk in an informal way, ${ }^{9}$ honeypot 'the vagina' (both originating as metaphors), buckshee 'gratis' (from the Persian baksheesh 'a gift of money') and zubrick 'the penis' (from the Arabic zubrak 'the penis'), all four of which have made their way into RS dictionaries. ${ }^{10}$ Granted, the perceptual salience of the stressed, rhyming elements (or "rhymemes", as they are technically termed) of these expressions would seem to trigger an association with chat, twat, free and prick respectively. However, that is not to say that these terms were motivated by rhyme, rhyme-motivation being a sine qua non for a word to qualify as RS. Many synonyms simply rhyme by chance. Sometimes, as in the case of buckshee and zubrick, the connection with a rhyming synonym may just be an attempt to make sense of a word that might otherwise seem conspicuously foreign. ${ }^{11}$ But how can we ascertain whether a rhyme is coincidental or not? How can we know if there really was an intention to rhyme at the time of coinage? This can only be determined with some (though not absolute) certainty by looking at three aspects: the context and period in which the word in question was coined, its semantic and morphological characteristics and the overall lexical structure of the dialect or dialects in which it is first recorded.

It is clear from what we know about the origins of RS that any supposed rhyming term that pre-dates the 1830s is to be regarded with suspicion. An interesting example is Jane Shore, from the name of the celebrated mistress of Edward IV and several prominent noblemen (ca. 1445-1527). To be sure, the story of the royal mistress (the merriest of the king's concubines, according to Thomas More) must have inspired the early, pre-RS use of the name as an epithet, as in the following quotation from a letter from Horace Walpole to George Montagu, dated 28 January 1760:

He apostrophized the lost sheep, who sobbed and cried from their souls; so did my Lady Hertford and Fanny Pelham, till I believe the city dames took them both for Jane Shores. ${ }^{12}$

1760 was too early for RS. Anyone would know what a figurative Jane Shore was without necessarily resorting to the rhyme with whore. A similar example of the use of this epithet, superficially closer to RS because of the humorously rhyming form in which it is couched, is found in one of Richard Barham's Ingoldsby Legends, originally published in 1840:

While Louis Quatorze

Kept about him, in scores,

What the Noblesse, in courtesy, term'd his "Jane Shores,"

- They were call'd by a much coarser name out of doors. - $^{13}$

\footnotetext{
${ }^{9}$ Quinion, 69-70.

${ }^{10}$ Chew the fat (Puxley, Fresh Rabbit; Green, Cassell's Rhyming Slang; Crozier; Tibballs; Finch), honey pot (Puxley, Cockney Rabbit; Tibballs), buckshee (Puxley, Cockney Rabbit), zubrick (Seal).

${ }^{11}$ Admittedly, the change from -eesh to -ee in buckshee and from -ak to -ick in zubrick was perhaps due to the influence of free and prick. Cf. buck shee (Connolly, 118), an uncommon spelling conforming to the usual bipartite structure of RS.

${ }^{12}$ Walpole, 39.

${ }^{13}$ Ingoldsby, 262.
} 
However, the earliest unquestionable occurrence of the name as RS is in an article on London slang published in 1893. The immediate company the word keeps in the quotation below, especially the synonymous twos and fours and the self-explanatory slap bang (the latter a nonce-word or an idiolectalism), leaves no room for doubt:

Members of the unfortunate class are referred to as Jane Shores or twos and fours, so that Slap Bang is frequently an attempt at euphonism. ${ }^{14}$

Green's ever-growing database of anglophone slang, which in 2014 contained some 125,000 words (including derivatives, compounds and phrasal uses), shows that RS accounts for five per cent of the lexis. ${ }^{15}$ In purely statistical terms, a slang usage is therefore quite unlikely to be a RS formation. In fact, according to Green's figures, it is just as likely to be an abbreviation and three times as likely to be a semantic extension or other type of manipulation of an existing standard English word. On the other hand, the database on which Lillo and Victor's dictionary is founded, which runs to in excess of 9,000 RS terms hailing from different corners of the English-speaking world, reveals another signature trait of this form of slang: rhyming terms occur in bunches; no dialect has just one item of RS. Thus, a word is likely to be RS if there are other words in that dialect that have been created as RS.

Given these premises, it is easy to see why the American slang eighty-six 'to reject, veto or dispose of someone or something; to put an end to something; to murder', originally used by waiters and waitresses to mean that an item was out of stock, ${ }^{16}$ is scarcely likely to have been coined as RS for nix (pace OED2 and most current dictionaries). ${ }^{17}$ Indeed, why should this be the one piece of American restaurant jargon that originated as RS? It is also telling that, although Barry Popik has traced the word back to 1933, the RS explanation of its origin first turns up in Harold Wentworth and Stuart Berg Flexner's dictionary, published in 1960.

But one should also be careful when confronted with sets of RS items. RS being but a small part of the lexis of English, it cannot be the first resort of the etymologist in attempting to discover a word's origin. I am assured, for example, that luscious glory 'a person's hair', a nonce-word coined by Anthony Burgess in A Clockwork Orange, ${ }^{18}$ is simply a playful variation of the standard English crowning glory; yet it was tentatively interpreted by Stanley Edgar Hyman and others after him as RS on upper storey (which, incidentally, is unheard of in the sense of 'hair' ${ }^{19}$ simply, I think, because this kind of slang is conspicuously present in Burgess's novel. A similar case is the adjective and adverb pan loaf, as in "That Hannah Gordon's a bit pan loaf, is she no"?"20 and "We don't huv tae talk pan loaf", ${ }^{21}$ a figurative usage whose currency in Glasgow, one of the traditional spawning grounds of RS, has triggered the following suggestion:

\footnotetext{
${ }^{14}$ St. Louis Post-Dispatch, 15 June 1893.

${ }^{15}$ Green, Language!, 18.

${ }^{16}$ See Bentley, 45; Adams, 61.

${ }^{17}$ See also Dundes, who does not buy that explanation either, although he accepts another popular myth.

18“"Then I put my nogas into very comfy woolly toofles, combed my luscious glory, and was ready for P.

R. Deltoid.” Burgess, 37.

${ }^{19}$ Hyman, 23. As far as I can tell, the usual slang sense of upper storey is 'the head as the seat of reason and intelligence', as in 'He's a bit weak in the upper storey'.

${ }^{20}$ Sunday Mail, Glasgow, 8 September 2002.

${ }^{21}$ Sunday Herald, Glasgow, 22 March 2009.
} 
A pan-loaf accent is a posh accent. There are two possible explanations for this usage known to me: the first being that a pan loaf was considered the kind of bread that posh people ate, the second being that pan loaf is rhyming slang for toff as pronounced locally. ${ }^{22}$

Rhyming coincidences between semantically related words are something of a minefield for the slang etymologist. And, for some odd reason, etymological guesswork based on them seldom fails to catch the public's fancy, regardless of its plausibility or the strength of the evidence. One prime example is the popular theory, perhaps originally propounded by Hugh Gray, that attributes the origin of brass tacks (as used in the phrase get or come down to brass tacks) to the rhyme on facts:

How many people realise, when they use the expression: "Let's get down to brass tacks," that this is a contribution to current speech taken from rhyming slang? The average Cockney pronounces the word "facts" to rhyme with "tacks," and the rhyming slang therefore for "facts" is "brass tacks." 23

Based on nothing more than a rhyming link, this explanation ignores the fact that the expression has a far longer history in American English than in British English. Furthermore, it seems to imply that the rhyme tacks-facts is more common in Cockney than in other dialects of English, which is, of course, not true. Eric Partridge, who helped perpetuate this misetymology in his Dictionary of Slang and Unconventional English, ${ }^{24}$ downplays the importance of the American evidence in the OED Supplement, while Julian Franklyn explicitly notes the phrase is "Cockney rhyming slang". The earliest citation for this idiom, posted by Fred Shapiro on the American Dialect Society mailing list, is from a Texan newspaper of 1863:

[W]hen you come down to "brass tacks"-if we may be allowed the expression-everybody is governed by selfishness[.] ${ }^{25}$

The date and place of publication are revealing: given that the first homegrown American specimen of RS did not surface until the $1880 \mathrm{~s}^{26}$ and the use of RS in America has always, in the main, been restricted to certain sporting and criminal subcultures on the West Coast, especially in San Francisco, ${ }^{27}$ we may conclude from this evidence that the phrase is unlikely in the extreme to be based on rhyme.

Bogus rhyming etymologies may even arise by association with existing RS terms. Take, for instance, the British idiom not a sausage 'nothing at all', which is often claimed to derive from sausage and mash, rhyming on cash. Examination of the evidence clearly shows this does not hold water: not a sausage is first found (with

\footnotetext{
${ }^{22}$ Munro, 53.

${ }^{23}$ Gray, 33.

${ }^{24}$ Partridge, Dictionary of Slang, 1 st ed.

${ }^{25}$ The Tri-Weekly Telegraph, Houston, Texas, 21 January 1863, quoted by Fred Shapiro on ADS-L, 7 November 2006, http://listserv.linguistlist.org.

${ }^{26}$ The earliest recorded item I am aware of is Little Joe 'a roll of four in craps', which first surfaced in print in the Cincinnati Enquirer of 12 June 1886: "Four was the throw. 'Shake dies, niggah, shake dies!' spoke a man about ten shades blacker than the man he addressed as 'niggah.' 'Wetcher throw, coon?' 'Little Jo.[']" The term relies on a mock dialect pronunciation of Joe as Jaw, thus rhyming on four. The word rhubarbs 'the suburbs' is recorded much earlier (1854), but does not conform to the canonical pattern of RS.

${ }^{27}$ See Maurer; Blumberg.
} 
reference to lack of money) ${ }^{28}$ in Philip Allingham's 1934 autobiography Cheapjack, ${ }^{29}$ whereas the earliest evidence we have for the noun sausage 'cash', shortened from sausage and mash, is from a 1948 article by English novelist James Curtis. Curtis himself, it so happens, was also probably the first to come up with the hypothesis that not a sausage is RS:

There are all sorts of colloquialisms used in English today which are based on a piece of rhyming slang of which the rhyme has long since been forgotten. An excellent example of this is that word 'sausage.' Frequently one hears people say 'not a sausage,' meaning a complete lack of something or another. Without knowing it, they are emulating M. Jourdain, by using rhyming slang. 'Sausage,' as we already know, means cash and when anyone wished to convey that he had no cash he would explain that he 'hadn't a sausage'. ${ }^{30}$

The same kind of anachronism explains why the long-cherished popular explanation of the word weasel in the nursery rhyme "Pop Goes the Weasel" cannot be right. In this explanation, the song is about pawning (popping in slang) either one's coat or one's suit in order to pay for drinks at the local pub, a reflection of the tough times faced by the English drinking classes in the olden days:

Up and down the City Road,

In and out the Eagle,

That's the way the money goes,

Pop goes the weasel.

Whether the "popped" article is a coat or a suit depends on the interpretation of weasel as an elliptical form of weasel and stoat ${ }^{31}$ or an alteration of the first element of whistle and flute. ${ }^{32}$ An apparent snag with both these interpretations is that weasel and stoat and whistle and flute are first recorded, respectively, in 1946 and 1931, ${ }^{33}$ whereas the origins of the song can be traced to mid-nineteenth century America. ${ }^{34}$

A different hypothesis suggests that weasel is Cockney RS for bezel 'a rim which holds a watch-glass in position'. ${ }^{35}$ This is untenable on several counts, though, not least because half rhymes are extremely uncommon in RS - Cockney or otherwise.

Another manifestation of this penchant for RS etymologies is to be found in the hypothetical full forms that have been concocted to explain the origin of certain words. Popular myth has it, for example, that kettle 'a wristwatch' is an elliptical form of kettle

\footnotetext{
${ }^{28}$ Hence Partridge's definition of sausage as 'any trifling sum of money' (Partridge, Dictionary of the Underworld). This is a slight development from the figurative sense the word has in the phrase not worth a sausage, whose use can be traced back to at least the early 1910s: "Nobody knows better than M'Clain that there isn't a white man in sight at present 'worth a sausage'[.]” The Barrier Miner, Broken Hill, NSW, 24 November 1911.

${ }^{29}$ “Of all the bloomin' carsies I've ever struck this 'ere takes some beating. They ain't got a sausage, son, not a sausage. I've taken more in a couple of hours on a Sunday in the rag-market than I'd take here in a couple of weeks." Allingham, 37.

${ }^{30}$ Curtis, 282.

${ }^{31}$ Irving Lewis Allen, 159; Holder, s.v. pop ${ }^{3}$; Foster, 97; Jack, 159-60; cf. Opie and Opie, 218.

${ }^{32}$ Foster, 97; Barry Hill, 25.

${ }^{33}$ The first appearance of weasel and stoat 'a coat' that I can trace is in an article on British slang published in the New York Times Magazine of 17 February 1946: "[T]he outrageous price of a 'whistle and flute' (suit) or a 'weasel and stoat' (overcoat) is a subject much discussed over a glass of 'pig ears' (beer)." Whistle and flute is first found in Brophy and Partridge.

${ }^{34} \mathrm{Cf}$. Raph, 131.

${ }^{35}$ Nettel, 232.
} 
on the hob, rhyming on fob. ${ }^{36}$ Likewise, frail has been derived from frail frame, rhyming on dame; ${ }^{37}$ onions, as used in the phrase know one's onions, has been etymologised as a shortening of onion rings, rhyming on things; ${ }^{38}$ the Mancunian slang bobbins 'rubbish' has been taken to be short for bobbins of cotton, rhyming on rotten; ${ }^{39}$ the South African English word bowl 'to steal', recorded in use among speakers of Indian descent, has been tentatively derived from bat and bowl 'stole'; 40 and tanner 'a sixpence' has been claimed to be the reduced version of tanner and skin, ${ }^{41}$ a phrase which, according to Partridge, could be RS for thin, another term for a sixpence. ${ }^{42}$ Try as I might, I have been unable to find any of these supposed full forms in any of the sources available to me.

\section{The "rhyming slangification" of ordinary slang words}

The explanations of the origins of some slang terms bear witness to the folk tendency to create unsubstantiated associative links between words. However historically false these links may be, once they become strong enough through repetition, they can have an effect on the shape of existing non-RS words, which may be elongated to rhyme with a synonym and hence achieve RS status. A case in point is bob 'a shilling; thus, in the plural, money', which has been rhyming slanged as Bob Dylan (courtesy of the Bard of Minnesota):

Sorry I can't, unless u can sort me with some bob dylans until Friday. ${ }^{43}$

I'm absolutely boracic lint. I was out with a lemon last night in the pub, so I thought you might gi' us a rub-a-dub-dub [sc. a sub]. A Bob Dylan. ${ }^{44}$

Given that the logical line of development of RS is FULL FORM > ELLIPTICAL FORM, as in Quentin Tarantino > Quentin, a predictable consequence of this transmogrification is that Bob Dylan is bound to be misinterpreted as the immediate etymon of the 'elliptical' form bob. This is in fact the etymology given for a few bob on Slang.ie, a popular crowdsourced dictionary of Irish slang:

A Few Bob n. A bit of cash. from rhyming slang; Bob Dylan = shillin' (currency pre-1970) a shilling was worth 12 pence (d); 20 shillings made $£ 1 .{ }^{45}$

There is no doubt that the primary reason for the coining of Bob Dylan was a wish to establish a (perhaps tongue-in-cheek) connection between bob and shilling. Whereas the usual type of RS phrase simply relies on the existence of a target word or "underlying etymon" (shilling, for example, is the "underlying etymon” of Thomas Tilling), Bob

\footnotetext{
${ }^{36}$ See Alexandrowicz and Wilson, 107; Sanger, 55.

${ }^{37}$ Spears.

${ }^{38}$ See Siefring; Baker, 63.

39، And gobby Liam couldn't resist sticking the knife in, telling him: 'Your cooking is bobbins.' The word is Manchester rhyming slang for lousy, as in bobbins o' cotton ... rotten.” Daily Star, London, 3 June 2008.

${ }^{40}$ Mesthrie.

${ }^{41}$ Hotten, Slang Dictionary, 68.

${ }^{42}$ Partridge, Slang To-day and Yesterday, 162.

${ }^{43}$ Urban Dictionary, entry posted on 3 May 2006, https://www.urbandictionary.com.

${ }^{44}$ Bill Hill.

${ }^{45}$ Slang.ie, accessed on 1 March 2013, http://www.slang.ie.
} 
Dylan hinges on two existing words, a "nested etymon" (bob), which is embedded within the word itself, and an "underlying etymon” (shillin'), both of them conveying the same meaning:

\begin{tabular}{|c|c|}
\hline NESTED ETYMON & UNDERLYING ETYMON \\
\hline$b o b$ & shillin’ \\
\hline
\end{tabular}

\section{Bob Dylan}

One of the earliest examples of this form of compound etymology is Tommy O'Rann 'scran (i.e. food)'. The word, which is first found in Hotten's Dictionary of Modern Slang, probably came about from a desire to make sense of the earlier slang tommy 'food' (originally 'bread'), whose original motivation, still not fully elucidated, ${ }^{46}$ had long become obscured. Another, perhaps more familiar example which can be explained as the result of a double derivation is Duchess of Fife 'a wife', a term first attested in the early 1930s. Though formed as RS, the expression is likely to have arisen as an elaboration of the earlier slang dutch 'a wife', ${ }^{47}$ itself the origin of my old dutch 'one's wife or mother', a Cockney usage first recorded in 1882 in J. F. Mitchell's ballad 'Jimmy Johnson's Holiday, ${ }^{48}$ and later used as the title of a popular music hall song by Albert Chevalier. Not suprisingly, the seemingly logical but unsupported assumption that dutch derives from Duchess of Fife is well-entrenched in the literature. ${ }^{49}$

English slang abounds in such compound etymologies. Yet, except in a few obvious cases, their identification is far from straightforward, for it requires demonstrating, on the one hand, that the RS phrase postdates its presumed nested etymon (this is no easy task, since most words are older than their first attestation in print) and, on the other, that both were used in the same dialect or dialects at around the same time. Thus, at first blush, one might think that apples and rice 'nice', first recorded by Partridge in $1943,{ }^{50}$ could well have been based on the slang apples (as used in the phrase she's apples 'everything is fine'), whose earliest attestation in the Australian National Dictionary is from $1929 .{ }^{51}$ It is a tempting etymology, but the geographical distribution of each of these forms militates against it: the RS expression has not been encountered outside of British English, whilst the non-RS apples is confined to Australian and New Zealand usage. For the same reason, the widely held hypothesis that the direction of development could have been apples and rice $>$ apples is at odds with the evidence. ${ }^{52}$

Fortunately, some expressions give the etymologist much less trouble. Any competent speaker of English intuitively knows that the slang words pins and pegs 'the legs' have been hanging around the language long enough to be the source of the British

\footnotetext{
${ }^{46}$ See Green, Green's Dictionary of Slang.

${ }^{47}$ This is probably an elliptical form of the slang Dutch clock 'a wife' (see Green, Green's Dictionary of Slang), rather than, as generally thought, a clipping of duchess.

48،"He made a vow he'd never row / With his old Dutch again”, quoted in Green, Green's Dictionary of Slang, s.v. Dutch n. ${ }^{4}$.

${ }^{49}$ See, for example, Koopman.

${ }^{50}$ Partridge, Dictionary of Slang, 3rd ed.

${ }^{51}$ Moore, ed.

${ }^{52}$ See Lillo, “Etymology of Australian Slang.” Most authorities claim that apples may derive from apples and rice or apples and spice. To my knowledge, the latter phrase is unrecorded.
} 
RS pin pegs and pins and pegs, both of which can be traced back to the early 2000s. ${ }^{53}$ The direction of development is clear and requires no hard evidence other than our own language competence and etymological awareness.

All too often, nonetheless, as with other areas of etymological research, here we can only discuss a word's origin in terms of probabilities rather than certainties, especially because the exact influence of a lexeme on the creation of a synonymous RS phrase is hard to ascertain in hindsight. The fact that tommy and dutch, mentioned above, were in common use in Cockney when Tommy O'Rann and Duchess of Fife were first found seems to suggest the latter derive from the former. It would be surprising to discover that they are etymologically unrelated, but linguistic accidents do happen - and they happen a lot in slang.

The same chronologically based analysis may apply to many other expressions. Twist and twirl 'a girl', for example, is commonly thought to be the source of the slang twist 'a girl', yet the earliest known use of the RS phrase is found in $1898,{ }^{54}$ while the monolexemic twist is first recorded in $1662^{55}$ and was probably still in use in the late nineteenth century; if determining when a word was first used is often difficult, determining when it went out of use is far trickier, if not impossible, especially in slang. ${ }^{56}$ Accordingly, unless it can be proved that, in its modern use, twist does derive from twist and twirl and the existence of the earlier twist is simply a coincidence (it is not unusual for two superficially identical lexemes to have quite distinct genetic histories), we may conclude that twist $>$ twist and twirl is more likely than twist and twirl > twist.

It will be clear by now that we are faced here with one of the major problems of slang research: how to date a part of a non-standard lexis which is essentially oral, often ephemeral by nature and whose written record is generally scant and unreliable, especially for earlier periods. The difficulty varies from one word to another, depending on the amount of evidence available. For instance, the narrow one-year gap between the earliest attested use of sugar and honey (1859) ${ }^{57}$ and sugar (1858), ${ }^{58}$ both used to mean 'money', does not allow us to determine with any degree of certainty which of these forms was coined first. However, we can be almost certain, pace the Dictionary of the Scots Language, that the Scottish gangland slang Malky Fraser 'a cut-throat razor', first recorded in an etymological note in Michael Munro's The Patter, ${ }^{59}$ originated as an elaboration of malky, which made its first appearance in print in Cut and Run by Bill McGhee. ${ }^{60}$

Below are some other words resulting from the combination of a nested etymon (identified as ETYM.1) and an underlying etymon (identified as ETYM.2). The dates of their first recorded use, enclosed in square brackets, and the varieties of English where they have been found are taken from Lillo and Victor's dictionary, which provides dated citations and further details. Unless otherwise stated, the dates of first use of the nested etymons are extracted from Green's Dictionary of Slang:

Charlie Britt. [1984] A fit of temper. Australian use.

$<$ charlie $^{\mid \text {|ETYM.1| }}$ [1941, in the phrase chuck a charlie 'to have a fit'] + fit ${ }^{\mid \text {|TYM.2| }}$

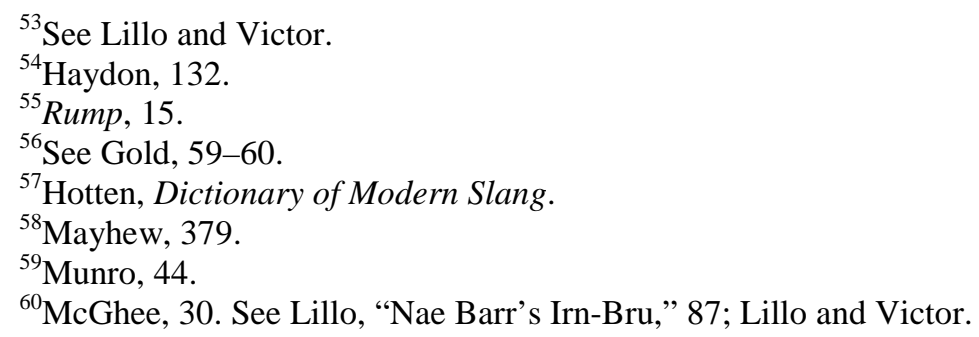


Charlie Hunt. [1961] An obnoxious person; an idiot. British use.

$<$ charlie $^{\text {|ETYM.1| }}[1946]+$ cunt $^{\mid \text {ETYM.2| }}$

Ching Wang Louis. [2006] A five-pound note. British use.

ching $^{\mid \text {ETYM.1| }}[2000]+$ bluey $^{\mid \text {|ETYM.2| }}$

dickory dock. [1960] The penis. British and Australian use.

dick $^{\text {|ETYM.11 }}[1836]+$ cock $^{\mid \text {ETYM.2| }}$

dog and bark. [1977] A police informer. Australian use.

$<\operatorname{dog}^{\mid \text {|ЕTYM.1| }}[1856]+$ nark $^{\mid \text {|ЕтYM.2| }}$

dog's meat. [2001] The feet. British use.

$<\operatorname{dogs}^{\mid \text {ETYM.1| }}$ 1916, OED3; the singular dog is recorded in 1913] + feet $^{\mid \text {|ETYM.2| }}$

hubba, I am back. [1994] Crack cocaine. American use.

$<$ hubba ${ }^{\mid \text {ETYM.1| }}[1986]+$ crack $^{\mid \text {|ЕтYM.2| }}$

Jack Dash. [2012] Money. British use.

jack $^{\mid \text {|ETYM.1| }}$ [1807, an originally American term recorded in British usage from the 1940s] + cash $^{|\mathrm{ETYM} .2|}$

Karsey Moilet. [2005] A lavatory. British use.

$<$ karsey $^{\mid \text {ETYM.1| }}$, variously spelt [1932] + toilet ${ }^{|\mathrm{ETYM} .2|}$

old fruit gum. [2011] Used as an affectionate form of address between men. British use.

$<$ old fruit $^{\left|{ }^{\mid \mathrm{TYM}} .1\right|}[1920]+$ chum $^{|\mathrm{ETYM} .2|}$

Peter Bell. [1992] A prison cell. South African use.

$<$ peter $^{\mid \text {ETYM.1| }}\left[1949\right.$; recorded in the form pete in 1934] + cell $^{\text {|ЕTYM.2| }}$

poppy red. [2006] Money. British use.

$<$ poppy $^{\mid \text {ETYM.1| }}[1943]+$ bread $^{\mid \text {ETYM.2| }}$

rat and mouse. [1961] A despicable person; a police informer.

rat $^{\text {|ЕTYM.1| }}[1818]+$ louse ${ }^{\mid \text {|ЕTYM.2| }}$

Scapa Flow. [ante 1945] To go; to run away; to leave quickly. British use.

< scarper ${ }^{\text {|ЕTYM.1| }}[1844]+$ go $^{\mid \text {|ЕTYM.2| }}$

Sprazey Anna. [1969] A sixpence. Also spelt Sprazy Anna, Sprazi Anna and Sprarsy Anna.

British use.

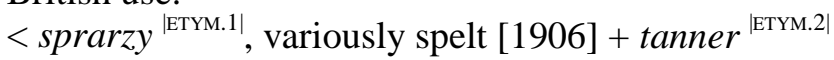

squiddly did. [2008] One pound sterling. British use.

$<$ squid $^{\mid \text {ETYM.1| }}[1902]+$ quid $^{\mid \text {|ETYM.2| }}$

Susie Anna. [1974] A sixpence. Also spelt Susy Anna and Suzianna. British use.

< susy |ETYM.1|, also spelt suzie [1934]; probably an alteration of the dialect form suse 'six' + tanner |Етум.2|

Thomas More; Thomas Moore. [2003; 2007] A female prostitute. British use. $<$ tom $^{\text {|ЕтYM.1| }}[1941]+$ whore $^{\mid \text {ЕTYM.2| }}$

As might be expected, the original motives for these coinages are not always easy to pinpoint. Most of them are consciously artificial and may be regarded as instances of intentionally playful folk etymology, simply prompted by a desire to juggle with words, to combine and recombine them in exciting new ways. The purpose of such play may be to remotivate an otherwise arbitrary-looking lexeme or to euphemise a word in a somewhat mischievous manner. The slang susie for a sixpence probably derives from the dialect form suse 'six', but it makes more sense if transformed into Susie Anna, rhyming on tanner. A similarly obscure word is the Lingua Franca and Polari verb scarper 'to escape', ultimately from the Italian scappare, which becomes more transparent when disguised as Scapa Flow, rhyming on go. The euphemistic quality of this kind of RS may be seen, for example, in dickory dock 'the penis' and Karsey Moilet 'a toilet', the jocular versions of dick and karsey.

Occasionally, elaborations may arise unintentionally too, and their origin can be pinned down precisely. One such expression is dog's meat 'the feet', a folketymological reconstruction of the Americanism dogs, often used in the phrase my dogs 
are barking 'my feet are sore'. So far as I can tell, the earliest occurrence of this expression is in OED2's definition of $\operatorname{dog}$ (n. ${ }^{1}$, sense 14 ), which is accompanied by a brief etymological note: ' $p l$. Short for dog's meat; feet. Rhyming slang'. It is reasonable to presume that it was this etymology that had some authors believe that dog's meat was a genuine usage; its consequent inclusion in a number of RS dictionaries, including Betty Kirkpatrick's, Ray Puxley's and Geoff Tibballs's, ${ }^{61}$ must have helped the expression take on a life of its own. Indeed, by the time the etymology of the relevant sense of dog was revised in the online OED3 ("It has been suggested that this is short for dog's meat, used as RS for feet, but there is very little evidence for such a use"), the term had already entered the RS lexicon as a modern substitute for the traditional and still commonly used term plates of meat (or plates for short):

So I'm going to find a clean dickie dirt, get on my dog's meat and I think today I'll need me quaker oat. ${ }^{62}$

\section{Some variations}

RS is an ongoing game whose rules are there to be, if not broken, at least bent to suit the speaker's needs and folk-etymological assumptions. This ludic nature of RS accounts for a vast array of variations on, or deviations from, the general formative patterns we are familiar with. While some of these variations may neatly fit into one or other of the conventional categories of $\mathrm{RS}^{63}$ the tangled web of word and sound associations underpinning them may be hard to unravel. One such variation is illustrated by Charlie Smirke. First recorded by Partridge in $1980,{ }^{64}$ the expression tautologically combines charlie and berk, its nested and underlying etymon respectively, but the latter happens to be a sanitised version of the more overtly dysphemistic RS term Berkeley Hunt or Berkshire Hunt.

This form of lexical recycling may be seen at work in other terms in which a shortened RS form is embedded in the word itself. Such is the case of the British slang Bristol bits, rhyming on tits, whose nested etymon is the singular form of bristols, a clipping of Bristol Cities, rhyming on titties. Likewise, rabbit, the short form of rabbit and pork 'to talk', has been recreated as rabbit's paw, rhyming on jaw:

This minger turned her back on her homeland and got to be famous just by shaking her Bristol bits on the telly. ${ }^{65}$

'Bunny' for them, first of all, meant 'slag' or 'whore' after the eponymous heroines of Playboy magazine. It also signified someone who was 'all mouth' and rabbits on (rhyming slang: rabbit's paw $=$ jaw): shades of the cockney singing duo, Chas and Dave. ${ }^{66}$

Taken to an extreme, this process can create a proliferation of synonyms for the same concept, a phenomenon that has been dubbed "overlexicalisation" 67 and which, in the case of RS, may reveal a desire to brighten up one's language and cause a chuckle or

\footnotetext{
${ }^{61}$ Kirkpatrick; Puxley, BritSlang; Tibballs.

${ }^{62}$ BritMovie (forum), entry posted on 16 July 2010, https://www.britmovie.co.uk/forum.

${ }^{63}$ See Lillo and Victor, xiii-Xv.

${ }^{64}$ Partridge, Dictionary of Slang, 8th ed.

${ }^{65}$ FCBA History (wiki), entry posted on 31 July 2015, http://fcbahistory.pbworks.com.

${ }^{66}$ Cohen, 26.

${ }^{67}$ Halliday, 571.
} 
two (slang, like poetry, abhors dullness), thus enhancing group bonding and, consequently, baffling, misleading and annoying outsiders. A notable example is brass, a common British slang term for a prostitute. Originally an abridged form of the RS brass nail 'tail (i.e. a prostitute)', ${ }^{68}$ the word not only has yielded several derivatives, compounds and blends, like brasser, brasshouse and brasstitute (this last a delightful nonce-word coined by Brendan Behan in his 1958 play The Hostage), ${ }^{69}$ but has also undergone such mutations as brass door, brass dart, brass flute and brass rubber, all of them based on a different underlying etymon (whore, tart, prostitute and scrubber):
Bonus Brass Door (= whore, get with my non-cockney muckers) points for her boudoir attire, all lacey and marabou feathers. ${ }^{70}$
I've been told 'brass' is rhyming slang; brass dart for tart. ${ }^{71}$
[A] binman won $£ 9.7$ million in the lotto, spent it all on drugs, Argos bling and brass flutes. $^{72}$
There's a bunch of old brass rubbers hanging around the car park. ${ }^{73}$

In still another variation of this process, a new RS phrase may result from a semantic development of an existing word. Lollipop 'money given as a gratuity or bribe' is a good case in point. The word, first recorded by Julian Franklyn, takes on its specific meaning from the rhyme on drop, its underlying etymon, but its nested etymon is lolly, a common slang term for money dating from the 1940s:

When he's a waiter Fred does well on lollipops. ${ }^{74}$

The same kind of double motivation can be seen at work in Dicky Dirt 'a shirt', a word coined in the 1890 s as an elaborated version of the earlier dicky 'a worn-out shirt; a false shirt front': ${ }^{75}$

Right, out come the old cutters, and with a quick snip his money and the tail of his Dicky Dirt were gone. ${ }^{76}$

\section{Concluding remarks}

From a strictly lexicological perspective, RS does not differ from most other subsets of English lexis (slang and otherwise): it is based on the attachment of new meanings to old forms. What makes it unique and sets it apart from other types of words is the use of rhyme as a disguise mechanism. Yet a close look at the RS lexicon will show that rhyme is often but one of several layers of associations upon which this type of slang is

\footnotetext{
${ }^{68}$ See Lillo and Victor.

69 “Call down that brasstitute.” Behan, act I.

${ }^{70}$ Le Blow (blog), entry posted on 8 June 2011, http://leblow.co.uk.

${ }^{71}$ The Guardian (website), comment posted on 30 June 2016, https://www.theguardian.com.

${ }^{72}$ Reddit (social news website), entry posted on 7 August 2016, https://www.reddit.com.

${ }^{73}$ Thom Bulter, pers. comm., 14 September 2017.

${ }^{74}$ Wilkes.

${ }^{75}$ See Lillo, “Origin of Cockney Slang.”

${ }^{76}$ Barnes, 75.
} 
built. The connection between a phrase and its target word may be based on a clever combination of rhyme and figurative language, as in cough and drag 'a fag (i.e. a cigarette)', or may rely partly on sociocultural knowledge, as in Stuart Diver 'a survivor', the eponymous Stuart Diver (b. 1970) being the sole survivor of the 1997 landslide in Thredbo, New South Wales. ${ }^{7}$

Sometimes, however, the very make-up of the word happens to be the result of a combination of two etymons. The technique of merging two etymons together to form a composite is in many ways comparable to that used in many false but widely believed etymologies of non-RS words, some of which have often been unquestioningly repeated in dictionaries and other literature. In fact, it would not be too far a stretch to venture that most rhyming slanged terms, like those discussed here, began life as pseudoetymological explanations. Rhyming slanged forms and spurious etymologies are therefore not to be seen as completely different animals, but simply as two different manifestations of our urge (call it natural if you will) to make sense of words that do not seem to make sense.

\section{References}

Adams, Michael. “The Server's Lexicon: Preliminary Inquiries into Current Restaurant Jargon.” American Speech 73, no. 1 (1998): 57-83.

Alexandrowicz, Alex, and David Wilson. The Longest Injustice. Winchester: Waterside Press, 1999.

Allen, Irving Lewis. The City in Slang. New York: Oxford University Press, 1993.

Allen, Robert. Allen's Dictionary of English Phrases. London: Penguin Books, 2006.

Allingham, Philip. Cheapjack. London: William Heinemann, 1934.

Baker, Richard Anthony. Many a True Word. London: Headline, 2013.

Barnes, Ron. Coronation Cups and Jam Jars. London: Centerprise, 1976.

Behan, Brendan. The Hostage. London: Methuen, 1958.

Bentley, Harold W. "Linguistic Concoctions of the Soda Jerker." American Speech 11, no. 1 (1936): 37-45.

Blumberg, Luba Monasevitch. Rhyming Slang. Unpublished MA thesis. University of California, Berkeley, 1968.

Brandon, H. "Dictionary of the Flash or Cant Language." In William Augustus Miles, Poverty, Mendicity and Crime. London: Shaw \& Sons, 1839.

Bronson, Charles. Loonyology. Clacton-on-Sea: Apex, 2008.

Brophy, John, and Eric Partridge. Songs and Slang of the British Soldier: 1914-18. 3rd ed. (1st ed. 1930). London: Eric Partridge Ltd at the Scholartis Press, 1931.

Burgess, Anthony. A Clockwork Orange. London: Heinemann, 1962.

Cohen, Philip. "Tarzan and the Jungle Bunnies: Class, Race and Sex in Popular Culture.” New Formations 5 (1988): 25-30.

Connolly, Jim. The Culchie’s Guide to Dublin. Cork: Mercier Press, 2009.

Crozier, Justin. Shame About the Boat Race: A Guide to Rhyming Slang. Bishopbriggs: HarperCollins, 2006.

Curtis, James. "Why Rhyming Slang?” The Saturday Book 8 (1948): 281-88.

Dictionary of the Scots Language. Dundee: University of Dundee. Available from http://www.dsl.ac.uk, 2004.

Dundes, Alan. “An Uplifting Origin of 86.” American Speech 76, no. 4 (2001): 437-40.

\footnotetext{
${ }^{77}$ For more examples, see Wright, 97-98.
} 
Finch, Sid. The Little Book of Cockney Rhyming Slang. Chichester: Summersdale, 2015. Foster, Sam. Hey Diddle Diddle: Our Best-Loved Nursery Rhymes and What They Really Mean. Chichester: Summersdale, 2008.

Franklyn, Julian. A Dictionary of Rhyming Slang. London: Routledge and Kegan Paul, 1960.

Gold, David L. “An Aspect of Lexicography Still Not Fully Professionalized: The Search for Antedatings and Postdatings (with Examples Mostly from English and Some from Other Languages)." Revista Alicantina de Estudios Ingleses 18 (2005): 25-69.

Gray, Hugh. "Rhyming Slang.” The Bookman, October 1934, 33-34.

Green, Jonathon. Cassell’s Rhyming Slang. London: Cassell, 2000. - Green's Dictionary of Slang. London: Chambers, 2010. Language!: 500 Years of the Vulgar Tongue. London: Atlantic Books, 2014.

Halliday, M. A. K. “Anti-Languages.” American Anthropologist, New Series, 78, no. 3 (1976): 570-84.

Haydon, Thomas. Sporting Reminiscences. London: Bliss, Sands \& Co, 1898.

Hill, Barry. The Road to Weatherfield. Rothersthorpe: Paragon, 2014.

Hill, Bill. “Talkin' Rhymin' Slang Blues”, from the album Bill Hill's Police Record, Alba MAR051 LP, 1978.

Holder, R. W. A Dictionary of Euphemisms. 3rd ed. (1st ed. 1987). Oxford: Oxford University Press, 1995.

Horn, Laurence R. "Spitten Image: Etymythology and Fluid Dynamics." American Speech 79, no. 1 (2004): 33-58.

Hotten, John Camden. A Dictionary of Modern Slang, Cant and Vulgar Words. London: John Camden Hotten, 1859.

. The Slang Dictionary. 5th ed. (with preface dated 20 December 1873). London: Chatto and Windus, 1874.

Hyman, Stanley Edgar. “Anthony Burgess’ Clockwork Oranges.” The New Leader 46, no. 1 (1963): 22-23.

Ingoldsby, Thomas [pseud. of Richard Barham]. “The Black Mousquetaire. A Legend of France” [Canto I]. Bentley’s Miscellany VIII (1840): 262-68.

Jack, Albert. Pop Goes the Weasel: The Secret Meanings of Nursery Rhymes. London: Allen Lane, 2008.

Kirkpatrick, Betty. The Little Book of Cockney Rhyming Slang. London: Michael O’Mara Books, 2001.

Koopman, Adrian. "Introducing 'My Old Dutch': Onomastic Attrition in Cockney Rhyming Slang and Titles of Nobility.” Nomina Africana 23, no. 1 (2009): 1-29.

Lillo, Antonio. “Origin of Cockney Slang Dicky Dirt.” Comments on Etymology 27, no. 8 (1998): 16-20.

. "On the Etymology of Australian Slang she's apples 'everything's O.K.'.” Leuvense Bijdragen 88, nos. 3-4 (2000): 477-81.

. “The Rhyming Slang of the Junkie.” English Today 17, no. 2 (2001): 39-45.

. "Nae Barr's Irn-Bru Whit Ye're oan Aboot: Musings on Modern Scottish Rhyming Slang.” English World-Wide 33, no. 1 (2012): 69-94.

—, and Terry Victor. A Dictionary of English Rhyming Slangs. Berlin: De Gruyter Mouton, 2017.

McGhee, Bill. Cut and Run. London: Hammond, Hammond, 1962.

Maurer, David W. “'Australian’ Rhyming Argot in the American Underworld.” Written in collaboration with Sidney J. Baker. American Speech 19, no. 3 (1944): 18395. 
Mayhew, Augustus. Paved with Gold, or The Romance and Reality of the London Streets. An Unfashionable Novel. London: Chapman and Hall, 1858.

Mesthrie, Rajend. A Dictionary of South African Indian English. Cape Town: UCT Press, 2010.

Moore, Bruce, ed. The Australian National Dictionary. 2nd ed. (1st ed. 1988). South Melbourne, Vic.: Oxford University Press, 2016.

Munro, Michael. The Patter. Glasgow: Glasgow City Libraries, 1985.

Nettel, Reginald. Sing a Song of England: A Social History of Traditional Song. London: Phoenix House, 1954.

Niedzielski, Nancy A., and Dennis R. Preston. Folk Linguistics. Berlin: Mouton de Gruyter, 2000.

Norman, Frank. Norman's London. London: Secker \& Warburg, 1969.

OED2 = Oxford English Dictionary. 2nd ed. Oxford: Clarendon Press, 1989.

OED3 = Oxford English Dictionary Online. 3rd ed. Available from http://www.oed.com, 2000-.

Partridge, Eric. Slang To-day and Yesterday. London: George Routledge \& Sons, 1933.

- Words, Words, Words! London: Methuen \& Co, 1933.

- A Dictionary of Slang and Unconventional English. 1st ed. London: George Routledge \& Sons, 1937.

—. A Dictionary of Slang and Unconventional English. 3rd ed. London: Routledge \& Kegan Paul, 1949.

- A Dictionary of the Underworld, British \& American. London: Routledge \& Kegan Paul, 1949.

- A Dictionary of Slang and Unconventional English. 8th ed. by Paul Beale. London: Routledge, 1984.

Popik, Barry. “Entry from July 01, 2005: '86' (not from Chumley’s or Empire State Building).” Available from https://www.barrypopik.com>, 2005.

Puxley, Ray. Cockney Rabbit. London: Robson Books, 1992.

- Fresh Rabbit. London: Robson Books, 1998. . BritSlang. London: Robson Books, 2003.

Quinion, Michael. Port Out, Starboard Home and Other Language Myths. London: Penguin Books, 2004.

Raph, Theodore. The Songs We Sang. South Brunswick, NJ; New York: A. S. Barnes and Co., 1964.

Randall, Tim. EastEnders Annual 2009. London: BBC Books, 2008.

Rump: or An Exact Collection of the Choycest Poems and Songs Relating to the Late Times. By the Most Eminent Wits, from Anno 1639 to Anno 1661. Vol. II. London: printed for Henry Brome at the Gun in Ivy-lane, and Henry Marsh at the Princes Armes in Chancery-lane, 1662.

Sanger, Jonathan. Making The Elephant Man. Jefferson, NC: McFarland \& Company, 2016.

Seal, Graham. Dog's Eye \& Dead Horse. Sydney, NSW: HarperCollins, 2009.

Siefring, Judith. The Oxford Dictionary of Idioms. 2nd ed. (1st ed. 1999). Oxford: Oxford University Press, 2004.

Smith, Noel "Razor". The Criminal Alphabet. London: Particular Books, 2015.

Spears, Richard A. McGraw-Hill's Dictionary of American Slang and Colloquial Expressions. 4th ed. New York: McGraw-Hill, 2006.

Thorne, Tony. Dictionary of Contemporary Slang. London: Bloomsbury, 1990.

Tibballs, Geoff. The Ultimate Cockney Geezer's Guide to Rhyming Slang. London: Ebury Press, 2008. 
Walpole, Horace. The Letters of Horace Walpole. Vol. III. Philadelphia: Lea and Blanchard, 1842.

Wentworth, Harold, and Stuart Berg Flexner. Dictionary of American Slang. New York: Thomas Y. Crowell, 1960.

Wilkes, Ian. London Rabbit. Romford: Ian Henry, 2004.

Wright, Peter. Cockney Dialect and Slang. London: B. T. Batsford, 1981. 